\title{
The Progress of the United Nations in Empowerment and Equality for Women
}

\author{
Pilar Gimenez Armentia, \\ Carmen de la Calle Maldonado and \\ Sonia González Iglesias
}

Additional information is available at the end of the chapter

http://dx.doi.org/10.5772/intechopen.76302

\begin{abstract}
In this chapter, the authors examine the work done by the United Nations to improve the status of women from its origin until 1995, when the fourth and final United Nations World Conference on Women took place. The study shall be divided into three periods. The first spans the era of legal defence of women's rights. The second period begins with the turn of events spurred by the Programme of Concerted International Action for the Advancement of Women in 1970 and continues with the proclamation of the United Nations' International Women's Year in 1975 and the United Nations Decade for the Advancement of Women (1975-1985). Over this 10-year period, three conferences were held: the one that took place in Mexico (1975), the one in Copenhagen (1980) and finally the one in Nairobi (1985). The third period takes a look at the Beijing Conference (1995) and the unprecedented advances it brought about in terms of equality. While the work done by the United Nations was undeniably valuable, as shown in this study, its efforts were not accompanied by marketing work that would have enabled it to make a greater impact on the international public opinion.
\end{abstract}

Keywords: woman, United Nations, equality, empowerment, marketing

\section{Introduction: the image of women and the fight for equality}

After the end of World War II and the failure of the League of Nations, in 1945 the International Community gave its approval for the creation of the United Nations, an organisation established to ensure world peace and security. From the outset, this institution has insisted upon the importance of the communication media in development and cooperation between 
nations. The first article of the Constitution of UNESCO, from 1945, states that the UN will always collaborate in the work of advancing the understanding of nations through the mass communication media, establishing such international agreements as may be necessary to promote the free flow of ideas and images.

The freedom of information is a topic that has been present in many of the covenants and agreements drawn up by the United Nations. Thus, in article 19 of the Declaration of Human Rights (1948), as well as in articles 18-20 of the International Covenant on Civil and Political Rights (1966), article 4 of the International Convention on the Elimination of All Forms of Racial Discrimination (1965) and article 2 of the International Convention on the Suppression and Punishment of the Crime of Apartheid, the subject of the freedom of information is mentioned as a fundamental, necessary, principle for the promotion of peace and understanding amongst human beings [1].

Three years after the United Nations was created, a conference on the freedom of information was held in Geneva. Based on this meeting, the rights, obligations and practices to be included within the concept of freedom of information were declared. This text places special emphasis on the fact that the free exchange of information and opinions is essential to the purposes of democracy and peace and for political, social, cultural and economic progress. To accomplish these aims, the media must be free from any kind of pressure, in virtue of its power to influence public opinion. This document stresses the significant responsibility that the media has towards the world and its duty to respect the truth and to promote understanding amongst all nations.

The UNESCO has endeavoured to foster, support and protect the work of the media and the professionals in this sector by creating covenants and agreements that benefit this commendable work. These conventions also aim to protect every human being's right to information while also stipulating certain obligations that all new organisations must fulfil.

However, in the early years of development of the United Nations, there are no serious references to women's status in the media or the impact that the media had on the image of women in the world. It was not until the Conference in Mexico that this subject was specifically addressed for the first time. The World Plan of Action from the meeting in Mexico recognised the importance of communication and information in improving women's status. Paragraphs 83 to 91 establish measures regarding education and the spread of information. These include a special emphasis on the sexist way in which women are portrayed, focusing on the importance of active participation by women in decision-making within the media. Finally, it is pointed out that there is a need to create educational programmes to eradicate the prejudices that restrict women's participation in society [2].

In 1980 in Copenhagen, emphasis was once again placed on this issue. However, it must be pointed out that in the questionnaire sent to the governments to assess the implementation of the Plan of Action of Mexico, no information was requested about the media, which leads to the conclusion that this was not a priority issue for the UN at that time. In fact, as noted in A Report on Action and Research Programmes, 1980-1985: "Yet it was not until three months before the Copenhagen Conference was to begin that a decision was taken, by the Preparatory 
Committee to the Conference during its third session, to call for a report on the role of the communication media. This last-minute attempt to 'pull in' the communication issue to the Conference agenda, whose parameters had actually long since been set, partly explains why the Conference did not finally come to grips in any serious way with the actual and potential role of communication media in the development of women's status" [3].

The Platform for Action of Copenhagen stresses the importance of the communication industry in changing the stereotypical image of women and notes that priority must be given to women's participation in taking decisions about communication.

Later, the chapter on Development at the Nairobi Conference in 1985 states that measures need to be taken as necessary to eliminate stereotypes in the media and to fully incorporate women into society. The document encourages the creation of programmes and allocation of resources to support domestic campaigns aimed at informing the public about the need for equality between women and men [3].

While the subject of women and communication media was discussed more thoroughly in Nairobi, it was at the Beijing Conference where the topic was truly addressed in-depth, giving it unprecedented importance. One of the critical areas of concern for the conference, contained in the "Beijing Platform for Action", was a section on women and communication media. This appendix, in addition to describing the situation in this sector and while admitting that significant changes have occurred, stresses that there is still a lot to be done. The document emphasises two strategic objectives. The first of these refers to the access of women to decisionmaking in the media and new communication technologies. The second refers to promoting a balanced and non-stereotyped image of women in the media. Under each of the objectives, certain actions are established, to be taken by governments, national and international media systems, the communication media, non-governmental organisations and the private sector to promote an active role by women. Some of the objectives proposed at this conference were encouraging the media to refrain from presenting women as inferior beings, sexual objects and commodities, removing sexist stereotypes from the media, taking measures against pornography and images of violence against women and girls and portraying an image of women as actors and beneficiaries of development.

These measures established to improve the image of women have not led to significant changes in marketing, and social stereotypes that do not benefit equality are still found in this area. While this subject has been of great interest to scholars and professionals who study the topic, with the first papers discussing gender differences in marketing [4] and the differing gender roles in advertising [5] published back in 1947, the fact is that this research has not had a noticeable impact in this field up to now.

In the advertising industry, sexist biases continue to be broadcasted, portraying a demeaning image of women, using them as a constant lure to sell and seduce male consumers. In turn, the projection of negative, degrading images of women in the communication media does not help foster or promote equality [6]. To the contrary, we might assert that this media stance is fostering and projecting a patriarchal, sexist society instead of paving the way for an egalitarian society. 
Although the UN's work, as evidenced throughout this chapter, has been commendable and entailed an incessant fight for equality between women and men, it is also true that, as we have just seen, this international organisation, in its origins, did not feature an attempt to change the image of women in the media or to launch marketing campaigns to mobilise public opinion in order to promote this equality. The United Nations has undeniably bolstered these campaigns, which have increased over the course of the years and left their mark on society, but just as the fight for the establishment of legal and institutional measures has been part of this organisation's work, the "sales campaign" for them has not been as productive as might have been expected; women were still forced into the background, and their image in the world remained that of the weaker sex that needed protection and care.

\section{The legal defence of women's rights (1945-1970)}

Ever since it was created in 1945, the objective of the United Nations has been to guarantee equality amongst all human beings and, more specifically, between men and women. Thus, in the Universal Declaration of Human Rights (1948), the organisation reiterated its commitment to promoting equality amongst people without distinction of their gender. These proclamations sparked intergovernmental actions taken in defence of women.

The Commission on the Status of Women created in 1946 was the first body in the United Nations system devoted to defending the status of women. The purpose of this Commission is to draw up recommendations and reports aimed at guaranteeing the rights of women under equal conditions with men in the political, economic, social, and educational spheres.

However, even before the creation of the UN, at the founding summit of the League of Nations (1919), women met at what could be called the "first parallel forum of NGOs". Over the next two decades, contacts between international non-governmental organisations for women and the League of Nations increased, placing pressure on the government delegations present at several summits on essential issues for women such as health, education, peace-keeping and disarmament, although an adequate legal and institutional framework was lacking [7].

It can be asserted that the earliest participation by women in the non-governmental sphere in drawing up international resolutions, conventions and declarations was in the area of labour rights, through the International Labour Organisation (ILO). The two objectives pursued by the ILO since its creation, in relation to female workers, were to protect their role as mothers and to promote equality between men and women in terms of employment. Both the contents of the conventions and the resolutions issued by the ILO have evolved from mere protection from a health and reproduction perspective, progressing towards the adoption of measures focusing on equal conditions and opportunities in employment [8].

The following conventions were issued during the years spanning from 1919 to 1970: Maternity Protection Convention (1919), Night Work (Women) Convention (1919), Underground Work (Women) Convention (1935), Equal Remuneration Convention (1951), Discrimination (Employment and Occupation) Convention (1958), Vocational Training Convention (1962), Employment Policy Convention (1964) and Workers with Family Responsibilities Convention (1965). 
During the course of 1966, two International Human Rights Covenants applicable to both men and women were approved. These were the International Covenant on Civil and Political Rights and the International Covenant on Economic, Social and Cultural Rights. These covenants bolstered the Universal Declaration by developing the rights contained therein, turning them into legal obligations for the governments of the countries that ratified or acceded to them.

There is a greater emphasis on the principle of equality between men and women in these two International Covenants than there is in the Declaration of Human Rights. While gender-based discrimination is mentioned in the Declaration of Human Rights as one of several types of distinctions, such as race or religion, in the International Covenants on Civil and Political Rights and on Economic, Social and Cultural Rights, an entire article is devoted to stressing that men and women are equally entitled to these rights. Amongst the rights proclaimed in the first of these covenants, some highlights are the right to marriage above a minimum age, consent by husband and wife and equal rights and responsibilities by both spouses in relation to the marriage, within marriage and in the event of dissolution thereof. The right to vote and to hold public office established in the 1951 Convention on the Political Rights of Women was also reiterated.

The United Nations gradually recognised and expanded the rights of women in the civil, political, economic, educational and labour arenas. The status of women was seen essentially as a legal concern by the UN in its early years. The demands were mainly related to access to education, health services, food, work in decent health and wage conditions, etc. [9]. However, during this first period, the UN failed to consider the causes of the inequality that half the population continued to bear merely because they were women. At that time, their marginalisation in decision-making, lack of power and the established roles for men and women did not find their way into the agenda of the United Nations.

In all fairness, we must mention that some early displays of a different perception of the feminine issue were also seen during this first period, in which women were no longer passive beneficiaries of development or vulnerable individuals with rights to be protected, to become actors in the economic and social development of the nations [10]. Starting in the late 1960s, the international community began to make the substantial change that would be seen in its strategy on issues related to promotion of women, based on their integration in the development processes.

\section{United Nations decade for the advancement of women (1970-1995)}

\subsection{Mexico 1975}

1975 marked a turning point in the promotion of equality between men and women as the year chosen by the United Nations to be International Women's Year and, at the same time, the first World Conference on Women took place in Mexico, which assessed and reflected on the activity that the UN had carried out up to that time in terms of the promotion of women, the results of which were not very satisfactory. The organisation itself was forced to acknowledge that its mainly legal activity had not achieved much in terms of improving women's status in the world. 
At this conference, a dialogue about equality between men and women was held on a global scale for the first time. Never before had the member states of the UN met to discuss agreed goals regarding gender equality, identifying obstacles and designing specific strategies to achieve such goals.

While, on a domestic scale, initiatives had been taken for the advancement of women, raising their participation in all spheres, the Mexico Conference gave these isolated steps forward a platform for institutional support and for implementation on a worldwide scale. The urgent need to improve women's status and the need to educate and train them to give them access to the same opportunities as men were seen at this conference.

In addition to equality, the Plan of Action of Mexico also set the goal of fully integrating women into the entire effort towards development. One of the objectives to be achieved was to increase the contribution of women to securing world peace. It was at this time that women began to be seen not just as passive victims of underdevelopment and conflicts but rather as active agents in the development and peace processes. The goals of equality, development and peace became the motto of the United Nations Decade for Women, declared by the UN at the urging of the conference for the period spanning from 1976 to 1985. The World Plan of Action outlined the fundamental goals of equality, development and peace and urged the governments of the signatory states to implement the necessary measures at national, regional and international levels to reach these goals by the end of the Decade for Women. In an effort to ensure their success, 14 minimum targets were set for the first half of the period. These included participations by women in the debates and in establishing guidelines, promotion of equal education and access thereto at all levels, highlighting the compulsory nature of primary education, reducing female unemployment rates, health, parity in exercising civil rights and the presence of women in decisionmaking bodies at local, national and international levels. The UN member states were to meet in Copenhagen in 1980 to assess the degree of achievement of these intermediate goals.

As a result of the Mexico Conference, the UN created two new bodies: the International Research and Training Institute for the Advancement of Women (INSTRAW), the purpose of which was to stimulate the advancement of women and their contribution to development through research, training and the spread of information [11], and the United Nations Development Fund for Women (UNIFEM), which would provide financial support and technical assistance to programmes promoting human rights for women and gender equality [12]. The work done by these agencies has been extremely important in improving the status of women around the world.

The UN General Assembly approved the Convention on the Elimination of All Forms of Discrimination against Women (1979). In its 30 articles, this document outlines the measures to be implemented in order to progressively eradicate all forms of discrimination against women in political and public life, in teaching, employment, health, marriage and the family and based on nationality. It represents a compilation of all the efforts made by the United Nations to incorporate the principle of gender equality into domestic laws. 


\subsection{Copenhagen 1980}

Five years later, the states met in Copenhagen to assess the degree of achievement of the World Plan of Action of the Mexico Conference, concluding that, while progress had been made in some of the goals, legal equality between men and women had not been implemented as expected due to obstacles such as insufficient political will, lack of acknowledgement of the value of women's contribution to society, a shortage of women in decisionmaking positions, insufficient services to enable women to perform their duties in national life, few credit facilities, a shortage of financial resources in general, limited participation by men in improving the role of women in society and a lack of awareness amongst women themselves as to the available opportunities, to name a few. With the aim of assisting women in exercising the rights entitled to them by law, governments were advised to attempt to eliminate these obstacles. Three areas were established, on which the signatory states and the UN agencies were to focus their efforts for achieving the goals of the World Plan of Action over the following 5 years. These were equitable access to education, equal employment opportunities and adequate healthcare.

In the Copenhagen Programme of Action, the signatory states agreed to increase the number of national measures to guarantee women's right to own property and control assets in general, to inherit, of custody of children and to nationality. In turn, the stereotypical images held of women were to be broken down by governments through campaigns aimed at advertising and the communication media.

The resistance that certain official delegations displayed towards the contents of the recommendations, which were incompatible with national legislation in numerous cases and with certain cultural principles that were deeply rooted in their societies, hindered consensus. The political tensions that had already begun to surface at the Mexico Conference grew stronger. Such is the case that the discussion came to a standstill and the final document was approved without reaching a consensus by all the participating states.

\subsection{Nairobi 1985}

After the Conference in Copenhagen, the third United Nations World Conference was held in Nairobi (Kenya) in 1985. The strategies set in Nairobi revolve around the three cornerstones: equality, development and peace. This document identifies the obstacles found to hinder the achievement of the goals defined in the principles for the decade and draws up basic strategies for the future and measures to be applied at the national level.

Within the subject of development, the subthemes of nutrition, water and agriculture, industry, trade and sales services, science and technology, communications, housing, settlements, development and transportation, energy, environment and social services were added to the subthemes of employment, health and education defined in Mexico. Special attention was given within the field of health to women and children under apartheid, Palestinian women and children and women in areas under the influence of armed conflicts, foreign intervention and threats to peace. 
This conference confirmed that the targets and goals set for the decade had only been partially achieved. While the early years of the decade had featured relatively favourable economic conditions in both developed and developing countries, the subsequent decline in the economic situation had prompted a drop in the pace of efforts aimed at promoting the equitable participation of women in society and had generated issues that forced a downturn in the cause for women.

The Nairobi Strategies represent such a change in the UN's focus on the issue of women's status that the organisation itself refers to this conference as the "birth of feminism on a global scale". For the first time, a document passed with full consensus by all the participating states takes an in-depth look at the cultural reasons behind the perpetuation of gender-based inequality and recommends that these obstacles be eliminated not only through legislation but also by educating the population in general, men as well as women.

In this document, the approach to equality is no longer exclusive in terms of nondiscrimination of women; instead, the signatory states make a commitment to implement legal and institutional mechanisms that encourage full participation by women in all occupations, particularly in realms that were once considered strictly masculine domain, in order to break down occupational barriers and taboos [10]. Special emphasis is placed on passing measures focused on ensuring equitable representation of men and women in decision-making bodies at all local, national and intergovernmental levels of politics. The fact that equality was no longer approached in terms of "non-discrimination" at this conference but rather as participation by women in all social spheres represents an important qualitative shift because it suggests a change in the very structures of society, in which women are active agents of this transformation. Another issue to be highlighted is the fact that this conference looks more closely at the cultural reasons behind the perpetuation of gender-based inequality and concludes that there are no physiological reasons to consider women as inferior to men nor are there any jobs or tasks specifically for women, and social structures are determined to be the essential element that perpetuates inequality.

In Nairobi, the need to intensify research on the status of women and the causes of discrimination of women became evident, and without actually giving it a name, the approach referred to as "empowerment" also began to take shape here, meaning the need to foster self-esteem, autonomy and greater access to power by women. Although the concept of "empowerment" pervades the Nairobi Strategies, the word itself does not appear for the first time until 7 years later at the International Conference on Population and Development held in Cairo, and it is also included in the Beijing Declaration in 1995.

Another topic that was stressed was the insistence upon taking measures at all levels to counteract gender violence. Violence against women was defined for the first time as "a major obstacle to the achievement of peace and the other objectives of the Decade" and was categorised as a critical area of concern.

In the non-governmental field, the International Women's Rights Action Watch, IWRAW, was created in Nairobi to track the Convention on the Elimination of All Forms of Discrimination against Women. 
And it was here that specific studies and actions were defined by the governments to eliminate stereotypes in the media and to incorporate women into society. This document also suggests applying research, creating programmes and allocating resources to support domestic campaigns aimed at informing the public about the need for equality between women and men [13].

\section{Fourth world conference in Beijing (1995)}

In 1995, the fourth United Nations World Conference was held in the capital of China, Beijing. At the same time, coinciding with the conference, the NGO Forum was held simultaneously, attended by more than 10,000 people from civil society. Preparations for this conference dated back to 1990, with preliminary regional summits held over the years to draw up proposals, which were recorded in regional documents and plans. These preparatory meetings helped to define the draft version of the Platform of Action, which would later be discussed in Beijing. However, despite all the work done, the Draft version of the Platform of Action lacked consensus, and more than $50 \%$ of the text was submitted without consensus [14].

The Beijing Conference had an unprecedented impact in the media, thus fully achieving the goal of any United Nations Conference of raising awareness amongst the public about the topics to be addressed. The fourth World Conference on Women in Beijing and the NGO Forum in Huairou generated an enormous mobilisation of the media. The events attracted more than 3200 journalists and people related to the media, compared to some 1400 at the 1985 conference in Nairobi and 800 at the conference in 1980. The Beijing Conference received more coverage than the preceding three conferences all together [15].

As a result of the conference, two documents were issued-the Beijing Declaration and the Platform for Action - which focused on 12 critical areas of concern for women, namely, poverty, education, health, violence against women, armed conflicts, the economy, women in power and decision-making, institutional mechanisms for advancement, human rights, the media, the environment and the girl child.

In Beijing, the term "gender" was introduced, defined as "socially constructed roles assigned to men and women, and the possibilities, opportunities and discriminations deriving from this" [9]. This new approach entails no longer dealing with women's status in an isolated manner but rather, in order for it to improve, changing the very structures of society, recreating more equal relationships between men and women. Thus, it is noted that the differences between women and men are not just biological but that there are also certain social structures that must be eradicated if full equality is to be achieved.

The United Nations conferences held during the first half of the 1990s had insisted on fostering equitable participation by men and women in order to achieve equitable, sustainable, human development. The fact that equality between men and women had found its way onto the United Nations' agenda, not just in the field of issues specific to women but integrated into other sector policies, shows that the mainstreaming of the issue had been evolving in the UN's agencies and organisations as well as in the governments of its member states. In Beijing, the 
commitment by the international community in terms of empowerment of women was bolstered, and systematic mainstreaming of the gender perspective was integrated into the policies. This posed a major step forward compared to the preceding conferences.

Hence, the adoption of positive measures focusing on ensuring equal representation of men and women in decision-making was recommended for the first time. The Platform acknowledges that women have lower rates of representation in decision-making positions due to the existence of barriers that are structural as well as ideological, which must be overcome by taking positive measures. Moreover, these measures should be taken not only by governments and political parties but also by trade unions, employers, industries and the private sector, research and academic institutions, non-governmental organisations and the UN system itself, to name a few, to achieve an increase in women's participation in decision-making in all aspects of public life.

There is also an insistence on parity and on the fact that women should reach influential positions, overcoming the invisible obstacles that prevent or hinder their access to executive positions, known as the "glass ceiling". To do this, we must have a decisive number of female leaders, executives and directors in strategic decision-making positions and in all areas of power and insist that governments must drive these measures.

In 1996, the Advisory Committee for Equal Opportunities of the Council of the European Union created a mainstreaming group. This group carries out educational activities and issues publications designed to provide guidance on integrating equal opportunities into the community's set of policies. These initiatives develop the principle of mainstreaming, giving the integration of the focus on gender in the assessment of national, regional and international policies a global boost.

Unprecedented progress was made in Beijing, recognised by the entire international community. Indeed, up to that time, the World Conferences on Women had been meetings by women or meetings to discuss issues that affected women. They were the sole recipients of the guidelines set or the measures proposed (...). However, in Beijing the international community took a step further to recognise, for the first time, that in order to achieve equality between women and men, a broader social change was needed, which not only affected women but also involved men [16].

Other accomplishments of the fourth Conference include spotlighting the precedence of women's human rights over religious beliefs, prioritising the educational and training needs of girls and women by donors and governments in development cooperation programmes, recommending that specific measures be taken to fight against violence affecting women, accepting rape committed during times of war as a war crime, recognising sexual violence as a reason for granting asylum, recommending that governments revise laws that punish women who commit or have committed abortion and calling upon the communication media to set up codes of conduct and self-regulatory mechanisms to eliminate stereotyped images of women.

Yet, as occurred at the three previous conferences, consensus did not reign in Beijing, and of the 2 documents approved, 44 reservations were expressed in relation to the Platform for Action, which show the degree of disagreement with the text issued. The document was criticised mainly for its lack of continuity with previous international documents, its ideological imbalance and the linguistic ambiguity that pervades the text. 
It is true that opinions vary as to the results from Beijing. According to the more or less progressive ideologies based on which women launched their reflections, the topics prioritised as achievements within the document sometimes varied substantially. When assessing issues such as poverty, education, work and the economy, there is little disagreement from one ideology to the next, and these are spaces in which building consensus has shown to be plausible. One of the specific achievements highlighted by women with progressive leanings was the recommendation that governments revise laws that punish women who commit or have committed abortion (...). The conservative sectors are the ones that made sharper criticism of the Platform for Action. These groups focused their criticism mainly on one area: women's reproductive health. Not in vain were these the only issues in which they showed any interest in the pre-Beijing period [16].

These views were also reflected in the communication media. Certain issues were handled by the press as successes or failures based on whether they were viewed as being "progressive" or "conservative". Certain newspapers even asserted that "the conservatives", with their backward ideas, had watered down the Beijing document. In this regard, it must be pointed out that the economic and political interests of the West often influenced the form and content of international news items. Because they control the communication media technology, they are considered agents of globalisation because they further the consideration of western values as universal values [17].

Despite the criticism, we can conclude that the Beijing Platform represented a step forward and the bottom line is positive. It is no wonder that the closing statements of the fourth World Conference on Women were made by the Secretary General of the Conference, Gertrude Mongella, who declared "A revolution has begun and there is no turning back", and there has been none. Beijing represented an unprecedented change that mobilised international public opinion, governments and women's movements, offering them the support and strength needed to progress in equality [18].

\section{Marketing and the gender perspective}

Not surprisingly, these efforts made by the United Nations and other public stakeholders in support of equality have, in some way or another, influenced both consumption and the market. Gender has managed to overcome social barriers and has been incorporated into every field, including the marketing sector. In this way, we find that the first conference on gender, marketing and consumption organised by the Association for Consumer Research (ACR) was held in 1991. This is just one example of countless conferences that have further studied such relevant issues as gender identity, differences between men and women in consumption, the sociocultural dimensions of the purchasing behaviour of men and women, lifestyles and consumer rituals [19].

As some researchers have asserted, the phenomenon of the working woman has probably had a greater effect on marketing than any other social change, since women are working and saving more than men, leading many industries to start considering marketing aimed at women [20]. 
Gender has opened up new lines of research in the field of marketing. Expanding the market perspective with the current social situation, conditions and context of women and men in mind can be advantageous for brands and companies. If we want to reach everyone, women must be included in the analysis of the exchange relationships, taking into account their viewpoints, which may differ from the predominant ones, and starting to think about new methods, new approaches and new instruments that are more aligned with the new social reality.

Although the gap between the female and the male realms is gradually shrinking, the marketing discourse still remains somewhat sexist, limiting women to the private sphere, confining them into preset images and definitions that do not describe their reality. The distribution of tasks continues to prevail, and it is easy to see that certain household products are only offered to women, men not being considered potential consumers. Women are still being used as a constant lure to sell and to seduce men, an object to be used, desired, had, purchased, enjoyed and discarded. Doing away with these degrading images and continuing to progress towards a gender perspective that pervades the entire marketing sector must be one of the priority goals set by this sector.

It is also important to recall that men are now facing new responsibilities, a certain identity crisis, new places in the private sphere, etc., whereas women are experiencing changes and social pressures and feeling that yearned-for "independence" that is starting to be a constant in their lives. Marketing professionals who are knowledgeable about these new needs will create better strategies to reach their audience better. Let us not forget that all current studies indicate that women take more purchasing decisions than men. On average, women affect $83-87 \%$ of the purchasing decisions in households and many brands and companies are attempting to attract female clientele because it is becoming clear that they are the ones who make the decisions and, thus, are the ones that must be swayed.

Market segmenting is one of the fundamental strategies of marketing. By integrating the gender perspective into product and service management, companies more effectively respond to the public's needs, developing new product ranges and, in this way, building loyalty.

There is still a long way to go, and we must free ourselves from the traditional marketing approach that held a completely masculine world view, endeavouring to abandon that old way of viewing and facing the world. We must support inclusive marketing that seeks to fulfil the needs of all human beings and respects and integrates human dignity in all its sales strategies. Marketing should promote justice and full personal development.

\section{Conclusions}

In this chapter, we have examined the work done by the United Nations to defend and implement equality for women throughout the world from the time it was created until the fourth and final United Nations World Conference on Women held in Beijing. Of the three periods into which the chapter is divided, the first focused on describing the period of legal defence of women's rights, spanning from 1945 to 1970. Originally, the fight was aimed at 
recognition of the political, labour, civil, educational and economic rights of women, setting the causes of inequality aside. It was not until the late 1960s that the international community began to change its approach and integrated women into the processes of change and global development. The second period begins with the turn of events spurred by the Programme of Concerted International Action for the Advancement of Women in 1970 and continues with the proclamation of the United Nations' International Women's Year in 1975 and the United Nations Decade for the Advancement of Women (1975-1985). Over this 10year period, three conferences were held: the one that took place in Mexico (1975), the one in Copenhagen (1980) and, finally, the one in Nairobi (1985). Starting in 1975, joint work would be done to improve women's status around the world. Never before had the member states of the UN managed to meet and agree on goals and specific actions regarding gender equality. For the first time in history, women were considered active agents of change, rather than mere spectators. The third period takes a look at the Beijing Conference (1995) and the unprecedented progress it brought about in terms of equality. This progress continues to be recognised today and implemented in the equality policies of the member states.

However, these efforts and achievements accomplished at the national and legal levels have not been reflected in the image of women globally. Despite the changes experienced, we continue to find sexist images and stereotypes spread throughout the marketing world. In fact, some products and the fact of purchasing them are associated with a masculine or feminine image that has no biological grounds, instead being based on stereotypes [21]. We must recall that, at this time, women are taking more purchasing decisions than men. Each year, we see how women surpass men in online purchasing, as the main consumers on the Internet. Therefore, it is imperative that the gender factor is included in the marketing field along with other demographic factors in order to explain behaviour or segment the market [22].

Political leaders and companies still have a long way to go in adjusting the legal framework that the UN has gone to such great lengths to establish over the years in terms of equality. This calls for mechanisms that allow for more permeable relationships between the two: integrating marketing information into the decision-making processes by public organisations and including broader social approaches into marketing [23].

As mentioned before, there is still a long road ahead for women to enter many areas of the public sphere with full rights and equal opportunities. Marketing is no stranger to this situation, and therefore, we must join forces in rejecting the old-fashioned marketing styles and turn to marketing in equality that benefits and supports full human development.

\section{Author details}

Pilar Gimenez Armentia*, Carmen de la Calle Maldonado and Sonia González Iglesias

*Address all correspondence to: p.gimenez.prof@ufv.es

Universidad Francisco de Vitoria, Madrid, Spain 


\section{References}

[1] Hilding E. Principios sobre uso de los medios de comunicación definidos por la ONU y la UNESCO. México: ILET; 1977

[2] Instituto de la Mujer. Las cuatro conferencias mundiales de Naciones Unidas sobre las mujeres. Madrid; 1993

[3] Naciones Unidas. La comunicación al servicio de la mujer. Conferencia Mundial para el examen y la evaluación de los logros del decenio de las Naciones Unidas para las Mujeres, Nairobi; 15-26 de julio de 1985; París: Organización de las Naciones Unidas para la Educación, la Ciencia y la Cultura

[4] Alexander R. Some aspects of sex differences in relation to marketing. Journal of Marketing. 1947;12:158-172

[5] Hawkins DI, Coney KA. Advertising and differentiated sex roles in contemporary american society. Academy of Marketing Science Journal. 1976;4(1):418-429

[6] Eisend M. A meta-analysis of gender roles in advertising. Journal of the Academy of Marketing Science. 2009;38:418-440

[7] Miller C, Razavi S. Gender mainstreaming: A study of efforts by the UNDP, the world bank and the ILO to institutionalize gender issues, UNRISD occasional paper 4; 1995. Fourth World Conference on Women

[8] Gaudier M. The Development of the Women's Questions at the ILO 1919-1994, 75 Years of Progress Toward Equality. Ginebra: Labour Institutions and Development Programme; 1994

[9] Hernández Zubizarreta I. Desigualdad de género en desarrollo Globalización y Género. Madrid: Síntesis; 1999

[10] Vázquez M, Villalba MR. La mujer en el mundo de hoy, situación y políticas de los gobiernos (Pekín 1995). Madrid: Escuela Libre; 1997

[11] López Méndez I, Sierra Legina B. Integrando el análisis de género en el desarrollo: Manual para técnicos de la cooperación. Madrid: Instituto Universitario de Desarrollo y Cooperación; 2001

[12] Naciones Unidas. Adopción de medidas a favor de la igualdad entre los géneros y el adelanto de la mujer, Mujeres. Nueva York; 2000

[13] Gimenez P. Un estudio de la IV Conferencia Mundial sobre las mujeres. Comunicación y Hombre. Madrid: Universidad Francisco de Vitoria; 2007

[14] Lara P. Notas sobre la IV Conferencia Mundial de las Mujeres. Madrid: Fundación Promoción Social de la Cultura; 1995 
[15] Gallagher M. From Mexico to Beijing and beyond: Covering women in the world news. Nueva York: The United Nations Development Fund For Women; 2000

[16] Solana Y, Rodríguez R, Rodríguez I, Santiago P. La larga marcha hacía la igualdad: IV conferencia mundial sobre las mujeres, Pekín 95. Evaluación del proceso en España, Ministerio de Trabajo y Asuntos Sociales, Instituto de la Mujer, Madrid; 1997

[17] Álvarez-Osorio E, Barreñada I. España y la cuestión palestina. Madrid: La Catarata; 2003

[18] Gimenez P. La imagen de las mujeres: Limitaciones y potenciales de los medios. Madrid: Fundación Universitaria Española; 2007

[19] Dema M, La S. Introducción de la perspectiva de género en el marketing: Una nueva forma de analizar las relaciones de intercambio. Estudios sobre consumo. 1997;81:55-69

[20] Lamb C, Hair J, y McDaniel C. Marketing. Ohio: Cengage Learning; 2008

[21] Gainer G. An empirical investigation of the role of involvement with a gendered product. Psychology and Marketing. 1993;10(4):265-283

[22] Lundstrom WJ, Sciglimpaglia D. Sex role portrayals in advertising. Journal of Marketing. 1977;41:72-79

[23] Cervera A, Calderón H, Mollá A. Market orientation: A framework for Public Institutions. Journal of Non Profit and Public Sector Marketing. 1999;7(1):3-24 
